\title{
Board of Directors' Remuneration, Employee Costs, and Layoffs: Evidence from Spain
}

\author{
Mariano González-Sánchez *(D), Eva M. Ibáñez Jiménez $\mathbb{D}$ and Ana I. Segovia San Juan (D) \\ Department of Business and Accounting, Faculty of Economics and Business Administration, National Distance \\ Education University (UNED), Paseo Senda del Rey, 11, 28040 Madrid, Spain; eibanez@cee.uned.es (E.M.I.J.); \\ asegovia@cee.uned.es (A.I.S.S.J.) \\ * Correspondence: mariano.gonzalez@cee.uned.es
}

check for updates

Citation: González-Sánchez, M.; Ibáñez Jiménez, E.M.; Segovia San Juan, A.I. Board of Directors'

Remuneration, Employee Costs, and Layoffs: Evidence from Spain. Sustainability 2021, 13, 7518. https:/ / doi.org/10.3390/su13147518

Academic Editors: Montserrat

Boronat Navarro, José A.

Pérez-Aranda and Marc A. Rosen

Received: 1 June 2021

Accepted: 1 July 2021

Published: 6 July 2021

Publisher's Note: MDPI stays neutral with regard to jurisdictional claims in published maps and institutional affiliations.

Copyright: (C) 2021 by the authors. Licensee MDPI, Basel, Switzerland. This article is an open access article distributed under the terms and conditions of the Creative Commons Attribution (CC BY) license (https:/ / creativecommons.org/licenses/by/ $4.0 /)$.

\begin{abstract}
Most of the empirical studies on board remuneration have focused on finding explanatory performance measures. There are studies that analyze if the compensation contracts of directors reward managers in such a way that they strive to maximize firm performance and shareholders' wealth; however, there are few studies on the social aspect of corporate governance, or agent-employee and principal-employee relationships. Thus, in this study, our aim is to test whether there is a causal relationship between the remuneration of the board of directors of listed companies and the personnel policies of the companies, expressed through the cost of personnel and layoffs. For that, we used a sample of Spanish listed companies, and we found that two performance measures (return on equity and earnings per share on market price) have a greater effect on the growth rate of board remuneration when layoffs occur. Additionally, we found that the sales revenue and cash flow on total assets subsequently influenced personnel management.
\end{abstract}

Keywords: firm performance; board remuneration; layoffs; personnel management

\section{Introduction and Background}

The theoretical framework of this study is agency theory, which assumes that the objectives of the firm's managers do not coincide with those of the shareholders. As a consequence, a vast field of research on managerial decision making and its effects on shareholder wealth has emerged. To avoid this situation, manager compensation based on performance measures that represent an increase in shareholder value has emerged. It is in this context that our empirical study analyzes whether such managerial compensation policies are conditioned by their decisions on employees. So, an important line of research is to analyze the explanatory variables of corporate board remuneration. Therefore, corporate governance studies have originated from the issues related to conflicts of interests between management and shareholders and directors' accountability to shareholders ([1-3]) and have given rise to different approaches to the same problem: the agency contract.

As a consequence, performance measures arise as variables used to remunerate boards of directors and at the same time explain shareholder wealth; thus, these performance measures as drivers of corporate governance represent common objectives for directors and shareholders. Several studies have analyzed the explanatory variables of board and executive compensation. For example, Merhebi et al. [4] found that Australian chief executive officer (CEO) compensation and firm performance showed a positive and statistically significant relationship. In addition, Doucouliagos et al. [5] analyzed the relationship between the CEO compensation and performance of Australian banks and found a positive relationship with earnings per share and that the return on equity lagged by two years. Lee [6] found that sales revenue was used by companies in Australian and Singaporean companies as a yardstick for determining CEO performance compensation; however, the structure of the board was not statistically significant. Kanapathippillai et al. [7] examined the link between a remuneration committee and attribution disclosures on Australian listed 
companies (2007-2011) and found that firms with this commission tended to voluntarily disclose attribution, and the extent of disclosures increased with remuneration committee quality. Other studies focused on whether executive compensation policies explain the behavior of firm performance. For example, Nasyikin et al. [8] found that directors' remuneration and board size had a negative relationship with firm performance, suggesting that high remuneration failed to motivate and retain directors that work harder for the best interest of shareholders. Noja et al. [9] explored the relationship between board and executive management compensation and remunerations and the financial performance of European companies and found that management financial incentives reverberate positively and significantly on the performance of European firms, leading to important gains in enterprise value and company earnings.

The above-mentioned empirical studies tended to rely on the theory of managerial compensation derived from agency theory and drew on the principal-agent relationship for testing if the compensation contracts of directors reward managers in such a way that they strive to maximize firm performance and shareholders' wealth. In addition, these empirical studies focused on the commercial side of agency theory, and neglected the social aspect or agent-employee and principal-employee relationships. As a result of the foregoing, Vitols [10] analyzed the impact of board level employee representation on the structure and level of management remuneration and on company performance in the 600 largest European listed companies (2005-2008) and found that higher employee representation in a company lowered total CEO remuneration. Furthermore, this representation did not have a negative impact on operating performance (return on assets) or on stock market valuation (market-to-book).

So, our aim is to analyze whether there is a Granger-causal relationship between the growth rate of the board of directors remuneration for Spanish listed companies and the personnel policy of the companies, expressed through employee costs and layoffs.

The Spanish case is relevant because, despite being one of the most important economies in the EU, it repeatedly presents the highest unemployment rates. In this context, there are several empirical studies on Spanish listed companies. For example, López-Iturriaga et al. [11] found that institutional investors are not a homogeneous group and that pressure-resistant directors fulfill a more thorough monitoring role. Fernández Méndez et al. [12] found that firms with busy directors offer low executive remuneration and present a low probability of a qualified audit opinion; additionally, this evidence was higher for large firms. Merino et al. [13] examined the connection between the characteristics of board of directors' and excesses in directors' remuneration for Spanish listed companies (2007-2012) and found that board size presents a nonlinear relationship with excessive total directors' remuneration during a crisis period. Finally, on non-financial Spanish listed companies from the years 2008 to 2016, ref. [14] analyzed the effect that board activity and board remuneration had on earnings management, using as proxy discretionary accruals, and found a U-shaped relation, indicating that excessive remuneration led to more earnings management. However, these studies did not investigate whether the personnel policies of the companies were one of the explanatory variables for directors' remuneration of Spanish listed companies.

Focusing on studies about the relationship between executive remuneration and layoffs, early empirical research are $[15,16]$. Ref. [15] examined the connection between layoffs, executive pay, and stock prices and found that firms that announced layoffs in the previous year paid their CEOs more and gave their CEOs larger percentage raises than firms that did not have at least one layoff announcement in the previous year. Elayan et al. [16] considered two hypotheses to explain employee layoffs by corporations, i.e., declining investment opportunities or efficiency. While the first hypothesis supposes a negative market response to employee layoff announcements, their results showed that layoffs per se increased the efficiency of the firm. Further research brought shareholders' concerns into the equation. So, Chen et al. [17] included in the equation the interests of stockholders and examined the relation between layoffs and stockholders' wealth and corporate performance subsequent to layoffs; they found that layoffs were preceded by a period of poor stock 
market and earnings performance, followed by significant improvements in both. Hahn and Reyes [18] conducted a study on daily market data of the stock market reaction to layoff announcements, where more than 1000 workers were affected, and found that the stock market responded negatively to layoffs attributed to low demand. Hillier et al. [19], on U.K. listed companies, showed that layoff announcements elicited a significantly negative stock price reaction, but layoffs resulted in significant increases in employee productivity. Some studies even focused on periods of crisis; for example, Marshall et al. [20] examined layoffs during the global financial crisis of 2008 and compared this with an earlier period of economic prosperity. They found a positive market reaction to layoffs during rising financial markets but stock price declines following employee layoffs during the 2008 financial crisis.

In addition, some empirical studies analyzed the non-contemporaneous relationship between executive pay and layoffs. For example, Billger et al. [21] studied the relationship between layoff announcements and CEO turnover over a 31-year period, and found that layoffs significantly increased CEO turnover in the following year, although this reaction was not constant over the sample period. Brookman et al. [22] found that CEOs with at least one year of tenure who possessed greater incentives from portfolios of restricted stock and stock option grants were more likely to announce layoffs, and that those layoffs created shareholder value. Brookman et al. [23] concluded that CEOs received pay increases following layoffs as rewards for past decisions and to motivate value-enhancing decisions in the future. Henderson et al. [24] examined the association between layoffs and CEO compensation and found that as layoffs intensified, CEOs' bonus compensations decreased and their equity-based compensations increased. Finally, and as a further example of the country focus, as a consequence of the regulatory differences in the labor market (among others), Jung et al. [25] examined if institutional investors and equity-based compensation incentives were associated with the implementation of asset divestitures and employee layoffs in France and found that layoffs were driven by inferior performance.

Therefore, our hypothesis is as follows: the firms' performance improvement Grangercause the increase of board remuneration, especially when layoffs or/and employee cost reducing occur. We test this hypothesis on a sample of Spanish listed companies from 2013 to 2019.

The remainder of this paper is arranged as follows: in Section 2, in materials and methods, we describe the methodology and data used for the empirical study; in Section 3, the empirical results are presented and analyzed; in Section 4, we discuss the empirical evidence found within the theoretical framework; and in Section 5, we provide our conclusions.

\section{Materials and Method}

\subsection{Methodology}

From the literature reviewed above, we observed that empirical studies on directors' remuneration and company performance suffered from the following drawbacks: nonlinear (U-shape for any variables, see [14,20]), unobservable heterogeneity of firms ([11,12]), endogeneity of data ([13]), and dynamic relationships ([5,15,21]). In addition, ref. [26] found a reverse causality between these variables, i.e., executive compensation influences company performance and vice versa. Additionally, it is possible that labor management influences company performance, executive compensation and vice versa.

Most empirical studies define the dependent variable as the logarithm of directors' remuneration (see [4,5], among others) and different measures of company performance as explanatory variables. The main drawback of this model is that, while the dependent variable is non-stationary, the independent variables are stationary, and therefore, the results on causal relationships are not consistent. As a consequence, our model only includes the following stationary variables. The dependent variable is the growth rate of directors' compensation that is estimated as $c_{t}=\frac{\operatorname{com} p_{t}-\operatorname{com} p_{t-1}}{\operatorname{com} p_{t-1}}$, where $\operatorname{comp} p_{t}$ is the total directors' compensation for year $t$. We also include two types of the independent 
variables: causal and control variables. Our causal variables are also divided into two types: performance measures and employees-related factors. We do this to test whether the effect of the firm's lagged performance measures on changes in board compensation (causality) is conditional on subsequent decisions on employee factors.

The performance measures included are all rates since dependent variable is a growth rate:

1. Return on assets defined as $R o A_{t}=\frac{E B I T_{t}}{A_{t-1}}$, where EBIT and $A$ are earnings before interest and tax and total asset, respectively.

2. Return on equity estimated as $R o E_{t}=\frac{E T_{t}}{E_{t-1}}$, where $E T$ and $E$ are total earnings and equity, respectively.

3. Price-to-book is $M t B_{t}=\frac{P_{t}}{B_{t}}$, where $P$ and $B$ are market price and book values of one share, respectively

4. Earnings price defined as $E P_{t}=\frac{E T_{t}}{n_{t}}$, where $n$ is the number of shares into which the company's capital is divided.

5. Market return calculated as $R m_{t}=\frac{P_{t}-P_{t-1}}{P_{t-1}}$.

6. Growth rate of sales revenue estimated as $s r_{t}=\frac{\text { Sales }_{t}-\text { Sales }_{t-1}}{\text { Sales }_{t-1}}$, where Sales is sales revenue.

7. Cash flow on assets defined as $C f o A_{t}=\frac{C f_{t}}{A_{t-1}}$, where $C f$ is the firm cash-flow of year $t$.

The employee-related factors are the following: the growth rate of employee number estimates as $l_{t}=\frac{E n_{t}-E n_{t-1}}{E n_{t-1}}$, where $E n_{t}$ is the number of employees in year $t$; layoff dummies that $D l_{t}=1$ when $l_{t}<0$ (otherwise, when the company does not decrease the number of employees $\left(l_{t} \geq 0\right)$, then $\left.D l_{t}=0\right)$; and growth rate of employee costs calculated as $e c_{t}=\frac{E m c_{t}-E m c_{t-1}}{E m c_{t-1}}$, where $E m c_{t}$ is employee costs of year $t$.

Finally, our control variables are as follows: firm size as log of total asset $\left(\operatorname{Ln} A_{t}\right)$; leverage of firm estimates as $l e v_{t}=\frac{L i a b_{t}}{A_{t}}$, where $L i a b_{t}$ is the company's liabilities in year $t$; dummies for each sample year $(D y)$ to collect economic cycle and dummies for industrial sectors (Ds) (see [13]) as (1) oil and energy, (2) basic materials, (3) manufacturing and construction, (4) consumers goods, (5) consumers services, (6) financial services and real estate, and (7) technology and telecommunications.

Thus, the model proposed to test the hypothesis is as follows:

$$
c_{i, t}=\sum_{j=1}^{7}\left(\beta_{1, j}+\beta_{2, j} \cdot l_{i, t}\right) \cdot P f_{i, j, t-1}+\varphi_{1} \cdot l_{i, t}+\varphi_{2} \cdot e c_{i, t}+\gamma_{1} \cdot L n A_{i, t}+\gamma_{2} \cdot l e v_{i, t}+\sum_{t=1}^{T} \delta_{t} \cdot D y_{t}+\sum_{s=1}^{7} \omega_{s} \cdot D s_{i, t}+u_{i, t}
$$

where sub-index $i$ shows firms $(i=1, \ldots, N)$ and $t$ is each sample year $(t=1, \ldots, T)$. Pf is each performance measured in year $t-1$. Since we are studying the causality relationship, in this regard, to avoid multicollinearity problems, we do not include measures with high correlations at the same time. Thus, from $j=1$ to $j=7$ represents $R o A, R o E, M t B, E P$, $R m$, sr and $C f o A$, respectively. Note that if $\beta_{1, j}>0$ shows the causality of performance measure $j$ on growth rate of the board remuneration $(c), \beta_{2, j}>0$ is the causality added as a consequence of the layoff decision, i.e., whether the effect of the performance measure is higher on the board's remuneration as a result of personnel layoffs. Additionally, $\varphi_{1}$ and $\varphi_{2}$ represent the contemporary relationship between changes on board compensation and employee number $(l)$ or employee costs $(e c)$. In addition, $\gamma_{1}$ and $\gamma_{2}$ collect the size effect on the remuneration of the board of directors. Finally, $\delta_{t}$ and $\omega_{s}$ show the year (economic cycle) and industrial effects, respectively.

In expression (1), $u_{i, t}$ is the residual on which we perform two types of tests. On the one hand, we use the Hausman test to determine whether the individual effect per firm is fixed $\left(u_{i, t}=\alpha_{i}+\epsilon_{i, t}\right)$ or random $\left(u_{i, t}=\alpha_{i, t}+\epsilon_{i, t}\right)$; in the first case, the estimation method is ordinary least squares (OLS), while in the second case, the consistent results are generalized least squares, using within-between weighting (GLS). On the other hand, we apply a autoregressive test (for lag-1 and lag-2) to analyze whether there is endogeneity 
in the model since, if they exist, the consistent results are those obtained by the generalized method of moments (GMM).

\subsection{Data}

Our sample consisted of Spanish companies listed during the period 2013-2019. Banks were excluded since, as a consequence of the 2008 financial crisis, they have been subject to merger and restructuring processes. In addition, those companies that, during the study period, were in merger, absorption or liquidation processes were excluded.

Financial information was obtained from the AMADEUS database, while information on board remuneration was obtained from the Spanish National Securities Exchange Commission (CNMV, Free download from, accessed on 28 December 2020: https: / www. cnmv.es/Portal/Publicaciones/Estadisticas-Remuneraciones-Cotizadas.aspx).

Our sample was comprised of 115 listed companies for a maximum period of 7 years per company, although the data panel was unbalanced, as information for all years was not available for all companies; therefore, the total number of observations in the data sample was 590.

Table 1 shows a statistical summary (panel A) and correlation matrix (panel B) of the data.

Table 1. Statistical summary of the data sample.

\begin{tabular}{|c|c|c|c|c|c|c|c|c|c|c|c|c|}
\hline \multicolumn{13}{|c|}{ Panel A. Statistical Summary } \\
\hline Statistic & c & 1 & ec & $\operatorname{Ln}(\mathrm{A})$ & lev & $\mathrm{sr}$ & $\mathrm{Rm}$ & EP & $\mathrm{MtB}$ & RoA & RoE & CfoA \\
\hline Mean & $8.92 \%$ & $1.42 \%$ & $4.68 \%$ & 137.907 & $70.77 \%$ & $3.32 \%$ & $3.68 \%$ & $12.70 \%$ & $177.42 \%$ & $3.49 \%$ & $12.05 \%$ & $6.72 \%$ \\
\hline Std. Dev. & $26.31 \%$ & $34.81 \%$ & $36.86 \%$ & 21.882 & $58.62 \%$ & $113.18 \%$ & $56.76 \%$ & $47.25 \%$ & $39.85 \%$ & $28.50 \%$ & $20.63 \%$ & $33.65 \%$ \\
\hline $\operatorname{Max}$ & $288.67 \%$ & $166.36 \%$ & $228.91 \%$ & 186.351 & $90.82 \%$ & $120.42 \%$ & $95.32 \%$ & $167.74 \%$ & $818.49 \%$ & $41.78 \%$ & $37.79 \%$ & $232.41 \%$ \\
\hline Min & $-64.60 \%$ & $-610.98 \%$ & $-235.81 \%$ & 78.216 & $14.76 \%$ & $-133.04 \%$ & $-27.06 \%$ & $-84.03 \%$ & $22.78 \%$ & $-35.05 \%$ & $-47.90 \%$ & $-312.13 \%$ \\
\hline \multicolumn{13}{|c|}{ Panel B. Correlation Matrix } \\
\hline c & 1 & $-0.0747 *$ & 0.1090 * & 0.0213 & 0.0312 & 0.0453 & 0.0267 & $0.0641^{*}$ & -0.0492 & 0.0201 & $0.0617^{*}$ & -0.0159 \\
\hline 1 & & 1 & 0.5312 ** & 0.0390 & -0.1142 * & 0.2118 * & 0.0531 & 0.0455 & 0.0343 & 0.0145 & 0.0204 & -0.1039 * \\
\hline $\mathrm{ec}$ & & & 1 & 0.0598 & -0.0214 & $0.3984^{* *}$ & $0.1206^{*}$ & $0.0635^{*}$ & -0.0230 & 0.0272 & $0.0837 *$ & -0.0965 * \\
\hline $\operatorname{Ln}(\mathrm{A})$ & & & & 1 & $0.4294^{* *}$ & -0.0117 & 0.0106 & -0.0388 & 0.0566 & 0.0423 & 0.0192 & -0.0112 \\
\hline lev & & & & & 1 & 0.0076 & 0.2016 * & $-0.1364 *$ & $0.1539 *$ & -0.0242 & $-0.1618^{*}$ & $0.0745 *$ \\
\hline sr & & & & & & 1 & 0.0874 * & 0.0502 & 0.0431 & 0.0105 & -0.0341 & -0.0703 * \\
\hline $\mathrm{Rm}$ & & & & & & & 1 & -0.0008 & $0.2996^{* *}$ & 0.0426 & 0.0266 & 0.0023 \\
\hline EP & & & & & & & & 1 & 0.0061 & 0.0423 & 0.1771 * & 0.1214 * \\
\hline MtB & & & & & & & & & 1 & 0.0304 & -0.2388 * & $-0.3608^{* *}$ \\
\hline RoA & & & & & & & & & & 1 & 0.0716 & $0.0785^{*}$ \\
\hline RoE & & & & & & & & & & & 1 & 0.1039 * \\
\hline CfoA & & & & & & & & & & & & 1 \\
\hline
\end{tabular}

Note: ${ }^{*}$ and ${ }^{* *}$ represent statistical significance at $5 \%$ and $1 \%$, respectively.

All statistics are expressed as percentages since they are rates and stationary variables, except for the control variable logarithm of total asset $(\operatorname{Ln} A)$. Note that the average growth rate of board remuneration is $8.92 \%$, while that of employee costs is $4.68 \%$, and that of the number of employees is only $1.42 \%$. Moreover, both the dispersion and the extreme values of these variables are higher for employees than for the board of directors. This could indicate that the impact of the company's performance does not influence both groups of individuals to the same extent.

In addition, we observe that the growth rate of the board remuneration has the highest correlations with the change in the number of employees $(-0.0747)$ and with personnel costs (0.1090). We also note that the highest correlations with respect to the performance measures are with EP (0.0641) and RoE (0.0617).

As a consequence of the data, in Figure 1 we show the average annual value of the growth rate of compensation to the board of directors versus the indicators related to personnel (top) and the most correlated performance measures (bottom). 

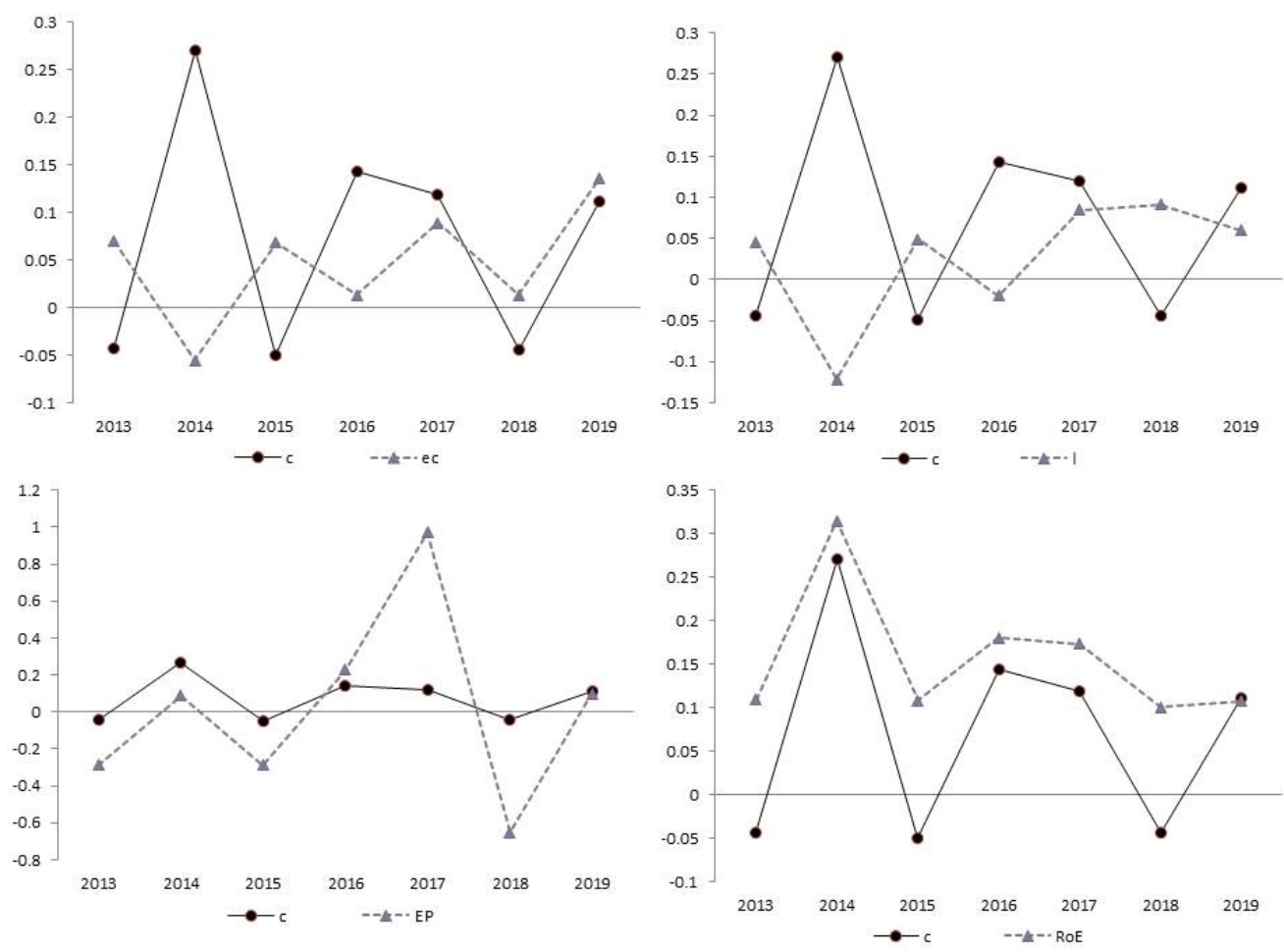

Figure 1. Average annual growth rate of board remuneration vs. employee and performance indicators.

From Figure 1, we note that the evolution over time of the growth rate of the board remuneration and personnel indicators is inverse, except for the last two years with respect to the cost of employees. In contrast, the evolution of board remuneration and performance measures are very similar.

\section{Empirical Results}

Table 2 shows the main results of this empirical research. The Hausman test, in all cases, accepts the random effects hypothesis. In addition, the autoregressive tests of the residuals indicate the absence of endogeneity and autocorrelation; therefore, the estimation method is GLS. In addition, we observe that the joint significance tests (Wald test) on the economic time effect and the industrial sector accept the null hypothesis of the absence of statistical significance. Finally, in Table 2, we show the significant regressors; the first three columns present the causal performance measures on changes in board compensation, number of employees, and cost of employees, and the last column shows the results of the model proposed in expression (1) to test our hypothesis.

As for the causality of the performance measures (first three columns of Table 2), we observe that board compensation shows a direct causal relationship with return on equity and earnings per share on price from the previous year; we also observe a positive size effect on growth rate of the board remuneration. Employee cost also shows a direct causal relationship with the return on equity of the previous fiscal year, but cash flow on total assets of two previous fiscal years also shows a positive causal relationship. The number of employees also shows a direct causal relationship with cash flow on total assets for the previous two fiscal years, as well as with the growth rate of the sales revenue for the previous two fiscal years. 
Table 2. Model estimation results.

\begin{tabular}{|c|c|c|c|c|c|c|c|c|}
\hline \multirow{2}{*}{$\begin{array}{l}\text { Dependent Variable } \\
\text { Regressors }\end{array}$} & \multicolumn{2}{|c|}{ c } & \multicolumn{2}{|c|}{1} & \multicolumn{2}{|c|}{ ec } & \multicolumn{2}{|c|}{ c } \\
\hline & Parameter & t-Value & Parameter & t-Value & Parameter & t-Value & Parameter & t-Value \\
\hline $\operatorname{Ln} A$ & 0.0031 & {$[2.261]^{*}$} & & & & & 0.0027 & {$[1.964]^{*}$} \\
\hline$E P_{t-1}$ & 0.0396 & {$[1.982] *$} & & & & & 0.0228 & {$[2.012]^{*}$} \\
\hline$R o E_{t-1}$ & 0.0270 & {$[2.231]^{*}$} & & & 0.0229 & {$[2.015]$ * } & 0.0172 & {$[1.982]^{*}$} \\
\hline$C f \circ A_{t-2}$ & & & 0.0832 & {$[2.063] *$} & 0.0462 & {$[1.967]^{*}$} & & \\
\hline$s r_{t-2}$ & & & 0.0578 & {$[4.191]^{* *}$} & & & & \\
\hline$D e_{t} \cdot E P_{t-1}$ & & & & & & & 0.0219 & {$[2.661]^{* *}$} \\
\hline$D c_{t} \cdot E P_{t-1}$ & & & & & & & 0.0195 & {$[3.402]^{* *}$} \\
\hline$E n_{t}$ & & & & & & & -0.1449 & {$[-1.975] *$} \\
\hline$E c_{4}$ & & & & & & & 0.3540 & {$[4.061]^{* *}$} \\
\hline Estimation Method & \multicolumn{2}{|c|}{ GLS } & \multicolumn{2}{|c|}{ GMM } & \multicolumn{2}{|c|}{ GMM } & \multicolumn{2}{|c|}{ GMM } \\
\hline Tests & test & $p$-Value & test & $p$-Value & test & $p$-Value & test & $p$-Value \\
\hline Hausman test & 1.028 & {$[0.607]$} & 0.9761 & {$[0.614]$} & 0.7830 & {$[0.676]$} & 17.230 & {$[0.423]$} \\
\hline Wald (industrial) $\chi^{2}(7)$ & 60.380 & {$[0.535]$} & 51.709 & {$[0.639]$} & 50.329 & {$[0.656]$} & 65.549 & {$[0.477]$} \\
\hline Wald (time) $\chi^{2}(6)$ & 40.109 & {$[0.779]$} & 37.046 & [0.813] & 38.970 & [0.792] & 41.712 & {$[0.76]$} \\
\hline $\mathrm{AR}(1)$ test $\mathrm{N}(0,1)$ & -1.292 & {$[0.196]$} & -0.5978 & {$[0.550]$} & 0.3496 & {$[0.727]$} & -0.5110 & {$[0.960]$} \\
\hline $\mathrm{AR}(2)$ test $\mathrm{N}(0,1)$ & 1.194 & {$[0.232]$} & -0.2796 & {$[0.780]$} & 0.4165 & [0.677] & 0.5819 & [0.561] \\
\hline$R^{2}$ for GLS or pseudo- $R^{2}$ for GMM & \multicolumn{2}{|c|}{$8.46 \%$} & \multicolumn{2}{|c|}{$6.22 \%$} & \multicolumn{2}{|c|}{$3.18 \%$} & \multicolumn{2}{|c|}{$10.68 \%$} \\
\hline
\end{tabular}

Note: ${ }^{*}$ and ${ }^{* *}$ represent statistical significance at $5 \%$ and $1 \%$, respectively. The $t$-value is estimated from standard errors consistent versus autocorrelation and heteroscedasticity.

Therefore, while board compensation depends on measures of earnings and stock market, employee figures are mainly caused (Granger-cause) by measures of liquidity and sales revenue. The results of the estimation of expression (1) (fourth column of Table 2) show both the effect size and causal relationship of performance measures (earnings per share on price and return on equity), although the causal effect of these performance measures is amplified when, during the fiscal year, there are layoffs and/or reduction in personnel costs; as a consequence, the hypothesis is accepted. Moreover, we find that there is a positive contemporaneous relationship between the growth rate of board remuneration and the growth rate of personnel costs, while with layoffs, it is negative, which supports the acceptance of the hypothesis.

Finally, note that the estimation method is GMM since we detected endogeneity problems for OLS and GLS when including employee-related factors. As consequence, we analyze whether such an endogeneity problem may be due to a causal relationship between employee-related factors and statistically significant performance measures. The results of this robustness analysis are shown in Table 3.

From the results of Table 3, we observe that dummy variables are not statistically significant. In addition, note that the return on equity explains earnings per share on price, while the causal-Granger variable on the return on equity is the growth rate of the sales revenue. Moreover, when, in the previous fiscal year, the firm has made layoffs (dummy layoffs with value 1), the effect of the causal variables on the performance measures increases.

In short, our results provide empirical evidence that the growth rate of the board compensations are determined by earnings on equity and earnings per share on price, i.e., remuneration increases according to the value of these performance measures in the previous fiscal year. Additionally, this positive effect is higher when the firm makes layoffs and/or personnel cost reductions. We also observe endogeneity problems, and the estimates show that reductions in sales revenue and/or cash-flow on assets will result in layoffs in subsequent years. 
Table 3. Results of robustness analysis.

\begin{tabular}{|c|c|c|c|c|}
\hline \multirow{2}{*}{$\begin{array}{l}\text { Dependent Variable } \\
\text { Regressors }\end{array}$} & \multicolumn{2}{|c|}{ RoE } & \multicolumn{2}{|c|}{ EP } \\
\hline & Parameter & t-Value & Parameter & t-Value \\
\hline$s r_{t-1}$ & 0.4791 & {$[3.482]^{* *}$} & & \\
\hline$D l_{t-1} \cdot s r_{t-1}$ & 0.3815 & {$[2.621]^{* *}$} & & \\
\hline$R o E_{t-1}$ & & & 0.1141 & {$[2.171] *$} \\
\hline$D l_{t-1} \cdot R o E_{t-1}$ & & & 0.2612 & {$[2.572]^{* *}$} \\
\hline Estimation Method & \multicolumn{2}{|c|}{ GLS } & \multicolumn{2}{|c|}{ GLS } \\
\hline Tests & test & $p$-Value & test & $p$-Value \\
\hline Hausman test & 1.5198 & {$[0.468]$} & 1.6055 & {$[0.448]$} \\
\hline Wald (industrial) $\chi^{2}(7)$ & 5.2093 & {$[0.634]$} & 3.6313 & {$[0.821]$} \\
\hline Wald (time) $\chi^{2} 6$ & 4.0408 & [0.775] & 2.3011 & [0.941] \\
\hline $\mathrm{AR}(1)$ test $\mathrm{N}(0.1)$ & -0.1504 & {$[0.880]$} & -0.9214 & {$[0.357]$} \\
\hline $\mathrm{AR}(2)$ test $\mathrm{N}(0.1)$ & -0.7682 & [0.442] & 0.6237 & [0.533] \\
\hline$R^{2}$ & \multicolumn{2}{|c|}{$4.33 \%$} & \multicolumn{2}{|c|}{$5.43 \%$} \\
\hline
\end{tabular}

Note: ${ }^{*}$ and ${ }^{* *}$ represent statistical significance at $5 \%$ and $1 \%$, respectively.

\section{Discussions}

This empirical study is situated within the general theoretical framework of agency theory. Then, we expect that managers have a disincentive to downsize because the benefits of running larger and more complex organizations are higher than minor firms (see [27]). However, as a result of the compensation structures for directors to align closely the interests of managers with those of shareholders, we also expect a greater propensity for directors to seek efficiency enhancements by employee reductions (see [28]) because employee downsizing reduces labor costs and boosts profitability. Therefore, linking executive compensation to the company's performance measures has an indirect negative effect on downsizing $([19,29])$. Thus, two opposing assumptions about the decision making of company managers and directors arise: on the one hand, not reducing the size of the firm; and on the other hand, increasing the profitability of the firm in order to increase the compensation received. So, our specific theoretical framework is the second one.

According to Datta et al. [30], the aim of employee downsizing is to improve firm performance. Datta et al. [30] group downsizing studies into four types, according to the factors that condition them and the outcomes that they produce: environmental and organizational factors, individual and organizational outcomes. Therefore, our objective is within the organizational factors.

Finally, Henderson et al. [24] examine the association between layoffs and CEO compensation and found that the preferential compensation arrangements afforded to more powerful CEOs are inconsistent with efficient contracting. Instead, the combined results are suggestive of the managerial power theory ([31]). So, under this theory, directors have the capacity to influence their compensation.

From our empirical results, we find evidence that supports the theory of directors power since, for Spanish listed companies in the period 2013-2019, we obtain a statistically positive significant relationship between the growth rates of director compensation and the prior year performance measures of firms; this positive relationship is higher as a result of downsizing during the fiscal year. In short, as the theory of managerial power points out, since their compensation is conditional based on the company's performance, managers have the ability to increase the firm's profitability through their decisions about employees, and thus, indirectly, to improve their compensation.

\section{Conclusions}

Under agency contract theory, there are many empirical studies on the explanatory variables of corporate board remuneration for analyzing the principal-agent relationship 
and testing whether the compensation contracts of directors reward managers in such a way that they strive to maximize firm performance and shareholders' wealth; however, there are few studies on the social aspect of corporate governance, or agent-employee and principal-employee relationships. Thus, in this study, our aim was to test whether there is a causal relationship between the remuneration of the board of directors of listed companies and the personnel policies of the companies, expressed through the cost of personnel and layoffs.

Our sample was comprised of Spanish listed firms (2013-2019) because despite being one of the most important economies in the EU, repeatedly, this country presents the highest unemployment rates.

From the literature review, we observed that the estimates present many problems, such as individual effects, heterogeneity, autocorrelation, and endogeneity. Therefore, we adjusted the estimation method of our unbalanced panel data according to these drawbacks (OLS, GLS, or GMM).

Our results indicated that return on equity and earnings per share over market price are the two performance measures that show a positive causal relationship with board compensation, and that this positive effect increases with layoffs. We also found empirical evidence that layoffs and the cost of personnel variations are influenced by variations in sales revenue and cash flow on assets from previous fiscal years. As a consequence, we accept the hypothesis that board compensation is Granger-caused by performance measures and that the effect is greater when layoffs occur.

An important implication of our results is that if decisions on layoffs are made by the board of directors and this positively affects their remuneration, it is necessary to control such decisions, for example, through employee representation on the board's remuneration committee. The significance of sales revenue and cash flow on total assets is also relevant; therefore, they should be variables with greater weight in the board's decision making and in parallel for personnel management.

Additionally, a limitation of our results is that the different regulations and functioning of labor markets in each country makes it difficult to directly extend our results to other countries.

Author Contributions: Conceptualization, M.G.-S., E.M.I.J. and A.I.S.S.J.; methodology, M.G.-S., E.M.I.J. and A.I.S.S.J.; software, M.G.-S., E.M.I.J. and A.I.S.S.J.; validation, M.G.-S., E.M.I.J. and A.I.S.S.J.; formal analysis, M.G.-S., E.M.I.J. and A.I.S.S.J.; investigation, M.G.-S., E.M.I.J. and A.I.S.S.J.; resources, M.G.-S., E.M.I.J. and A.I.S.S.J.; data curation, M.G.-S., E.M.I.J. and A.I.S.S.J.; writingoriginal draft preparation, M.G.-S., E.M.I.J. and A.I.S.S.J.; writing-review and editing, M.G.-S., E.M.I.J. and A.I.S.S.J.; visualization, M.G.-S., E.M.I.J. and A.I.S.S.J.; supervision, M.G.-S., E.M.I.J. and A.I.S.S.J.; project administration, M.G.-S., E.M.I.J. and A.I.S.S.J.; funding acquisition, M.G.-S., E.M.I.J. and A.I.S.S.J. All authors have read and agreed to the published version of the manuscript.

Funding: This research received no external funding.

Institutional Review Board Statement: Not applicable.

Informed Consent Statement: Not applicable.

Data Availability Statement: Our sample is available in the AMADEUS database and on the web (accesed on 28 December 2020) https://www.cnmv.es/Portal/Publicaciones/EstadisticasRemuneraciones-Cotizadas.aspx.

Conflicts of Interest: The authors declare no conflict of interest.

\section{References}

1. Jensen, M.C.; Meckling, W.H. Theory of the firm, Managerial behavior. agency costs and ownership structure. J. Financ. Econ. 1976, 3, 305-360. [CrossRef]

2. Fama, E.F. Agency problem and the theory of the firm. J. Political Econ. 1980, 88, 288-308. [CrossRef]

3. Fama, E.F.; Jensen, M.C. Separation of ownership and control. J. Law Econ. 1983, 26, 301-325. [CrossRef]

4. Merhebi, R.; Pattenden, K.; Swan, P.L.; Zhou, X. Australian chief executive officer remuneration, pay and performance. Account. Financ. 2006, 46, 481-497. [CrossRef] 
5. Doucouliagos, H.; Haman, J.; Askary, S. Directors' Remuneration and Performance in Australian Banking. Corp. Gov. Int. Rev. 2007, 15, 1363-1383. [CrossRef]

6. Lee, J. Executive performance-based remuneration. performance change and board structures. Int. J. Account. 2009, 44, 138-162. [CrossRef]

7. Kanapathippillai, S.; Mihret, D.; Johl, S. Remuneration Committees and Attribution Disclosures on Remuneration Decisions: Australian Evidence. J. Bus. Ethics 2019, 158, 1063-1082. [CrossRef]

8. Nasyikin, N.; Ibrahim, N.A.; Kassim, A.; Tamsir, F. How Does Directors' Remuneration and Board Structure Impact on Firm Performance in Malaysia Telecommunication Industry? Eur. J. Bus. Manag. Res. 2019, 4, 1-7.

9. Noja, G.G.; Cristea, M.; Jurcut, C.N.; Buglea, A.; Popa, I.L. Management Financial Incentives and Firm Performance in a Sustainable Development Framework, Empirical Evidence from European Companies. Sustainability 2020, 12, 7247. [CrossRef]

10. Vitols, S. Board Level Employee Representation. Executive Remuneration and Firm Performance in Large European Companies. European Federation of Employee Share Ownership Working Paper. 2010. Available online: http://www.efesonline.org/ database\%20of\%20employee\%20ownership/Users/2010_ceo_pay_paper.pdf (accessed on 12 September 2020).

11. López-Iturriaga, F.; García-Meca, E.; Tejerina-Gaite, F. Institutional directors and board compensation: Spanish evidence. Bus. Res. Q. 2015, 18, 161-173. [CrossRef]

12. Fernández Méndez, C.; Arrondo García, R.; Pathan, S. Monitoring by busy and overlap directors, an examination of executive remuneration and financial reporting quality. Span. J. Financ. Account. 2017, 46, 28-62. [CrossRef]

13. Merino, E.; Manzaneque-Lizano, M.; Sánchez-Araque, J. Sustainability and Corporate Governance, Transparency and Excessive Directors' Remuneration in Listed Companies during the Global Financial Crisis. Sustainability 2020, 12, 158. [CrossRef]

14. Saona, P.; Muro. L.; McWay, R.; Jara, M. Contrasting Incentives for Earnings Management, Board Activity and Board Remuneration in Spanish Firms. 2020. Available online: https:/ / ssrn.com/abstract=3710966 (accessed on 17 October 2020).

15. Hallock, K.F. Layoffs, Top Executive Pay, and Firm Performance. Am. Econ. Rev. 1998, 88, 711-723.

16. Elayan, F.A.; Swales, G.S.; Maris, B.A.; Scott. J.R. Market reaction. characteristics and the effectiveness of corporate layoffs. J. Bus. Financ. Account. 1998, 25, 329-351. [CrossRef]

17. Chen, P.; Mehrotra, V.; Sivakumar, R.; Yu, W. Layoffs, shareholders' wealth, and corporate performance. J. Empir. Financ. 2001, 8, 171-199. [CrossRef]

18. Hahn, T.; Reyes, M.G. On the estimation of stock-market reaction to corporate layoff announcements. Rev. Financ. Econ. 2004, 13, 357-370. [CrossRef]

19. Hillier, D.; Marshall, A.; McColgan, P.; Werema, S. Employee Layoffs. Shareholder Wealth and Firm Performance, Evidence from the UK. J. Bus. Financ. Account. 2007, 34, 467-494. [CrossRef]

20. Marshall, A.; McColgan, P.; McLeish, S. Why do stock prices decline in response to employee layoffs? UK evidence from the 2008 global financial crisis. J. Financ. Res. 2012, 35, 375-396. [CrossRef]

21. Billger, S.M.; Hallock, K.F. Mass layoffs and CEO turnover. Industrial Relations. J. Econ. Soc. 2005, 44, 463-489.

22. Brookman, J.T.; Chang, S.; Rennie, C. CEO equity portfolio incentives and layoff decisions. J. Financ. Res. 2007, 30, $259-281$. [CrossRef]

23. Brookman, J.T.; Chang, S.; Rennie, C. CEO Cash and Stock-Based Compensation Changes. Layoff Decisions, and Shareholder Value. Financ. Rev. 2007, 42, 99-119. [CrossRef]

24. Henderson, B.C.; Masli, A.; Richardson, V.J.; Sanchez, J.M. Layoffs and Chief Executive Officer (CEO) Compensation: Does CEO Power Influence the Relationship? J. Account. Audit. Financ. 2010, 25, 709-748. [CrossRef]

25. Jung, D.K.; Aguilera, R.V.; Goyer, M. Institutions and preferences in settings of causal complexity, Foreign institutional investors and corporate restructuring practices in France. Int. J. Hum. Resour. Manag. 2014, 26, 2062-2086. [CrossRef]

26. Aslam, E.; Haron, R.; Tahir, M.N. How director remuneration impacts firm performance, An empirical analysis of executive director remuneration in Pakistan. Borsa Istanb. Rev. 2019, 19, 186-196. [CrossRef]

27. Datta, D.K.; Guthrie, J.P.; Basuil, D.; Pandey, A. Managerial discretion and optimal financing policies. J. Financ. Econ. 1990, 26, 3-27.

28. Vicente-Lorente, J.D.; Suárez-González, I. Ownership traits and downsizing behavior: Evidence for the largest Spanish firms. Organ. Stud. 2007, 28, 1613-1638. [CrossRef]

29. Ahmadjian, C.L.; Robinson, P. Safety in numbers: Downsizing and the deinstitutionalization of permanent employment in Japan. Adm. Sci. Q. 2001, 46, 622-654. [CrossRef]

30. Datta, D.K.; Guthrie, J.P.; Basuil, D.; Pandey, A. Causes and effects of employee downsizing: A review and synthesis. J. Manag. 2010, 36, 281-348. [CrossRef]

31. Bebchuk, L.A.; Fried, J.M.; Walker, D.I. Managerial power and rent extraction in the design of executive compensation. Univ. Chic. Law Rev. 2002, 69, 751-846. [CrossRef] 